\title{
O SINTHOME COMO A HERESIA TEÓRICA DE LACAN
}

Pedro Heliodoro de Moraes Branco Tavares

Psicanalista e literato-germanista; doutor em Psicanálise e Psicopatologia Fundamental (Université Paris VII); doutor em Teoria Literária (UFSC).
RESUMO: Pretende-se demonstrar, a partir da leitura do Seminário 23 de Jacques Lacan, a transformação do conceito psicanalítico de sintoma na categoria de sinthome, defendendo a ideia de que o mesmo possa ser compreendido como uma espécie de nova e "herética" maneira de articular os registros do Real, do Simbólico e do Imaginário (RSI). Trata-se, nesta nova abordagem, de uma rearticulação com o que estava na origem do sofrimento, transformando um legado de falta e interdição em algo de própria e singular invenção. Da ligação ao elemento paterno-divino, trinitário (tanto em relação à organização borromeana como em relação à trindade católica), passa-se ao aparentemente caótico e mundano do "diabo a quatro" (do nó borromeu acrescido da quarta consistência e dos quatro elementos da matéria no mundo secular).

Palavras-chave: Sinthome, RSI, heresia, Lacan.

ABSTRACT: The Sinthome as Lacan's theoretical heresy. In the present work we intend to demonstrate, based on the 23rd Seminar by Jacques Lacan, the transformation of the psychoanalytical concept of symptom into the category of the Sinthome, supporting the idea that it can be understood as a new and "heretical" way of articulating the registers of the Real, the Symbolic and the Imaginary (RSI). The essence of this new vision lies in a reconceptualization of the origin of the suffering, transforming the symptom, comprehended as a legacy of lack and interdiction, into something of one's own and singular invention. From the bound with the tripartite parental/ divine element (of the borromean structure and of the catholic trinity), one switches to the secular "diabo a quatro" (Devil's four) (that of the borromean chain of four categories and also of the mundane four elements of matter).

Keywords: Sinthome, RSI, heresy, Lacan. 
$\mathrm{J}$ acques Lacan, em seu Seminário 23, propõe uma inovação em sua teoria, não só sobre o fim de análise, mas que vem reestruturar a concepção psicanalítica de sujeito e de cura. É necessário dizer que os conceitos do referido seminário estão longe de ser uma unanimidade inclusive no próprio meio psicanalítico. Há analistas que se embaraçam ao se referir a este "último Lacan”, dizendo que sua insistência com os nós topológicos e com os jogos de palavras seriam anódinos, irritantes e que ali ele já não mais falaria pela Psicanálise. Certamente é forte, principalmente essa última afirmação/negação, quando facilmente se percebe a complexa e coerente lógica interna de seus seminários e negação de sua aderência ao discurso psicanalítico, quando o que é questionado é principalmente uma de suas mais presentes inquietações desde Freud: o fim (enquanto término e finalidade) de uma análise.

Se é exagero dizer que sua doutrina deixa de ser psicanalítica, não o seria, entretanto, afirmar que ali ele passa a se pronunciar desde um lugar diverso: deixa de ser tão somente um freudiano como poucos anos antes ter-se-ia afirmado, ${ }^{1}$ para desenvolver uma posição lacaniana, ${ }^{2}$ o que se mostra na reviravolta epistemológica provocada pelo que traz o conceito que dá nome ao referido seminário: o Sinthome.

Nesse Seminário, ao longo de suas exposições, o estatuto da palavra e da interpretação é também revolucionado pelo recurso às palavras-valise, tropos, puns, entre outros jogos fonético-morfológicos e translinguísticos; recursos que devem sua inspiração a um literato: o escritor James Joyce. As palavras-valise são aquelas que se formam da fusão de significantes que se rompem, dando margem a diversas leituras. Joyce, exemplo dos processos linguísticos examinados por Freud nos fenômenos lacunares (sonhos, chistes, atos-falhos), como o paradigmático familionär ${ }^{3}$ de Heine (espécie de chiste baseado num possível ato-falho), seguindo a trilha aberta por Lewis Carroll, incorporava essas composições às suas produções.

No próprio título do referido Seminário, Le Sinthome, está colocado em ato este recurso. Ali, podemos constatar a grafia francesa antiga para um termo bastante corriqueiro e de grande importância no vocabulário psicanalítico. Mas, lendo-o como palavra-valise, podemos dali obter, além de sintoma (symptôme), também santo-homem (saint-homme), pecado-homem (sin-t-home) e quase, como será sugerido, São Tomás de Aquino (Saint Thomas d’Aquin), autor que inspirou James Joyce.

\footnotetext{
${ }^{1}$ Seminário de Caracas, última aula do Séminaire 27 — Dissolution (inédit) (12/07/1980).

${ }^{2}$ No Seminário 22 - RSI, chega a colocar ironicamente em questão se Freud seria lacaniano.

3 Palavra inexistente no léxico alemão, formada pela junção dos termos familiär (familiar/ familiarmente) e millionär (milionário). Conferir em Der Witz und seine Beziuhng zum Unbewu ten (FREUD, 1905).
} 
Um santo é evocado para tratar da heresia joyciana com a qual o psicanalista se identifica e aporta o invento em questão. Caberia aqui introduzir o outro aspecto do tropo: o RSI, a leitura da sigla em francês, faz o jogo homofônico com a heresia (RSI/hérésie). Essa sigla dá conta de algo central no ensino de Lacan, o que ele chamou de os três registros da experiência psíquica: o Real (R), o Simbólico (S) e o Imaginário (I). Essa seria a (santíssima) trindade do lacanismo, cujo próprio inventor vem retorcer ou heretizar ao fim de seu ensino para, contrariando a opinião de muito de seus ouvintes, reinventar o que estava na base de seus postulados.

O que vem a ser alterado, com a reviravolta dos últimos anos de seu ensino, não é exata ou simplesmente a concepção sobre cada um desses registros, mas sim a primazia dentre eles. Os três registros, ou antes, o arranjo entre eles, marcam coincidentemente fases no ensino de seu mentor-articulador.

O primeiro Lacan, já falando dos outros dois registros, privilegia o imaginário (IRS) através de seu escrito sobre o Estádio do Espelho (LACAN, 1949), onde apresenta o surgimento do Eu pela identificação imaginária a um outro, mesmo que a partir disso fique patente o engano provocado por essa identificação a essa Urgestalt (esta configuração inaugural ou originária). Lacan enfatiza ali ser esse o engano constituinte da concepção egóica que contribui para a crença na comunicação, no intersubjetivo. Este estádio, Lacan o caracteriza como

“Um drama cujo impulso interno precipita-se da insuficiência para a antecipação - e que fabrica para o sujeito, apanhado no engodo da identificação espacial, os fantasmas que se sucedem desde uma imagem despedaçada do corpo até uma forma de sua totalidade que chamaremos de ortopédica."4 (LACAN, 1949, p.96)

O segundo Lacan, o mais popular e difundido, é o que dá maior importância ao Simbólico (SIR) em seu ensino. É o Lacan que recorre aos linguistas (Saussure, Jakobson) e que dialoga com os estruturalistas (Lévi-Strauss, Foucault, etc.), da metáfora e da metonímia, do Inconsciente estruturado como uma linguagem, da primazia do significante em relação ao significado, etc. É o que dá conta do equívoco. "É do equívoco fundamental a este algo que se trata o termo do simbólico, no qual vocês sempre operam” (LACAN, 1974-5). O brilhantismo e a genialidade dessa fase, a forma como ela propõe um retorno "estruturado" à obra de Freud como jamais se vira, tornam compreensível para nós quanto à fixação de muitos e a aderência permanente desta fase ao nome de seu formulador, como espécie de verdade última. E isso, evidentemente, pelo que é relativo ao próprio registro do

\footnotetext{
${ }^{4}$ Todas as traduções das citações são de minha autoria.
} 
Simbólico: instaurar uma espécie de ó $\mu$ ('nomos'; princípio organizador-ordenador) mesmo que para Lacan não fosse o caso propriamente de criar um cânone.

O que está em cena no Seminário 23, porém, cuja emergência é, aliás, “preparada" pelos seus precedentes (ainda hoje oficialmente inéditos), é a primazia do Real (RSI), que Lacan já começa a esboçar ao longo dos seminários anteriores. Esse Real, já não sendo o mesmo de quando concebe o nó borromeu, é o que propõe como seu invento. Essa primazia, além do advento do Sinthome, que pretende rearticular os três registros, são as grandes novidades do seminário em questão. Sobre este terceiro registro, ele dirá: "Poderíamos dizer que o real é estritamente o impensável” (LACAN, 1974-5). Ele ex-siste, existe fora, como grafa Lacan. "Ele siste, talvez, mas não sabemos onde. Tudo o que podemos dizer é que isto que o con-siste não nos é acessível" (Idem). Isso porque a consistência é do âmbito do imaginário.

Mas antes de prosseguirmos, cabe fazer menção à ideia de como se articulariam esses três registros antes desse seminário: como uma cadeia onde um está unido ao outro de tal forma que, ao se soltar qualquer deles, os outros dois também se liberariam, como o aponta Lacan no Seminário 22, que merece justamente o nome RSI.

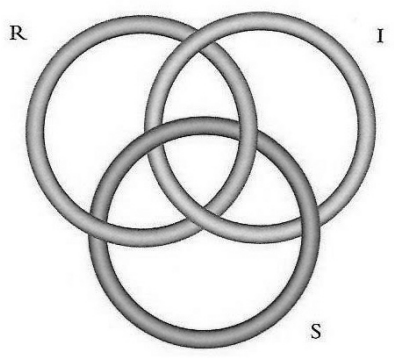

Nó borromeu: (R) Real, (S) Simbólico e (I) Imaginário.

É a partir da monstração do nó borromeu que parte sua constatação de estrutura mínima em três. "Algo começa no três que inclui todos os números seguintes a serem enumerados" (Idem). Tal constatação realmente faz-se notar, gera uma satisfação com a boa forma tridimensional da Gestalt imaginária por ele engendrada: “O nó borromeano, concebido suportando o número três é do registro do imaginário. É como o imaginário está enraizado nas três dimensões do espaço" (Idem).

O Sinthome, essa nova categoria que viria romper com a boa forma "tridimensional", como uma quarta consistência, ao seu modo, diante de uma ruptura na cadeia, viria propor uma nova atadura. Trata-se de desatar e reatar de um novo modo, distinto de todo o proposto até então. Uma operação sobre a qual, como 
tal, não se pode muito teorizar, il faut le faire (é preciso fazê-lo). Lacan insiste na necessidade de agir perante isso antes de produzir discurso, alusivamente, simbolicamente, a seu respeito.
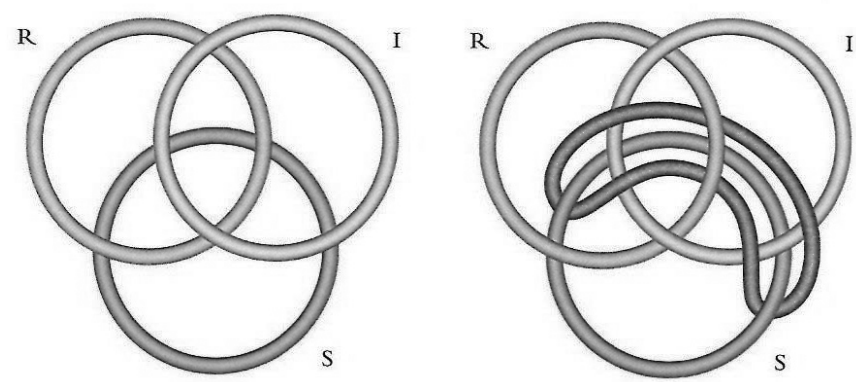

O Sinthome como a quarta consistência, que vem reatar o Real, o Simbólico e o Imaginário dispersos.

E aqui chegamos a algo fundamental acerca do Sinthome, conceito mais próximo do ato do que do sentido e, portanto, de difícil esclarecimento teórico. O sintoma no contexto analítico, esse sim, é um conceito no qual o sujeito se vê pleno de sentido, amarrado e estruturado simbolicamente. Mas, é diante da emergência do sem-sentido do sintoma, pela irrupção de algo da ordem do real, que o nó se desamarra, e é pelo Ato, e não pelo Verbo (simbólico), que se produz a nova amarração, o Sinthome. Ou seja, veremos que isso toca antes a um saber-fazer, próprio do Ato, do que a um discurso alusivo, próprio do Verbo.

Aqui poderíamos fazer uma analogia com o mito de Fausto, paradigma mor da literatura no que tange a uma heresia na busca de um artifício próprio, de um saber-fazer, tal qual abordamos em nossa tese de doutorado (TAVARES, 2007). No caso de Fausto, podemos estabelecer esta relação com a "re-ligação" no processo do pacto. Primeiro, é necessário que Fausto se depare com o sem sentido diante da sua teologia, ciência e filosofia, trindade que ele com tanto afinco estudou sem alcançar a fortuna espiritual, para que se compreenda o pacto como ato-artifício da nova aliança com um quarto elemento em descontinuidade com os três primeiros. Trata-se da ligação com Mefisto, imagem metonímica do Pai, destituída do lugar de ideal (Deus-Pai, onipotente, absoluto) com o qual se encontrava anteriormente ligado (pensando o que se preserva no sintoma analítico desta relação ao pai), para, enfim, passar de uma articulação ao saber enquanto mero conhecimento (gnóstico) para a categoria de um saber enquanto artifício, o saber-fazer. Da ligação ao elemento divino e apolíneo uno-trinitário, passa-se ao caótico e dionisíaco diabo a quatro. Ou seja, tratamos aqui da alusão que estes números três e quatro fazem da passagem de uma configuração organizada estética e topologicamente 
do Nó de três elementos, que Lacan remete à ordem da trindade católica, para uma configuração desequilibrada do ponto de vista do número assimétrico de entrelaçamentos topológicos e também de uma configuração estética de sua representação. Falamos da passagem para o nó borromeu de quatro estruturas, com o acréscimo do Sinthome. Do três divino (trindade da "verdadeira religião" católica), passa-se ao quatro mundano, dos quatro elementos da alquimia pagã, que fazem alusão não mais ao trinitário distante e divino, mas aos quatro elementos da matéria a que se tem acesso como matéria-prima.

A heresia do Sinthome, que tem no sintoma sua matéria-prima na concepção da clínica, é aquela que busca um saber-fazer ali, com o sintoma, uma via diversa para a "verdade revelada" a ser seguida e incorporada, como é o caso da claritas de São Tomás, santo padroeiro de Joyce. ${ }^{5} \mathrm{Ou}$ seja, não há mais uma busca por uma verdade a se revelar como conhecimento sobre o que fazer, mas um saber que só se desenvolve pelo fazer.

Não se trata se seguir o que Lacan chama de Sintoma-D’Aquin (Saint-thomadaquin), este madaquin como manequin, como modelo de conduta exterior ao sujeito, mas servir-se dele na invenção de um fazer próprio a que se refere pelo Saint-Home Rule. Este novo termo, o Home Rule (Governo/Lei Doméstica), é a referência ao clamor dos nacionalistas irlandeses, conterrâneos de Joyce, que procuravam um governo próprio, livre da dominação britânica. Joyce não tomará nem a posição da revolta denegatória desta lei do Outro nem a da servidão voluntária. Aí está sua heresia: na escolha (o que denota o étimo hairesis de heresia), na invenção de uma nova via.

Isto implica "ser herege de uma boa maneira, aquela que por haver reconhecido bem a natureza do sintoma, não se priva de usá-lo logicamente, quer dizer, até alcançar seu real ao cabo do qual não há mais avidez” (Idem, p.15). Avidez por quê? Por sentidos, já que se tratava da primazia do real e é pela junção do simbólico ao imaginário que, combinados, esses se produzem. É por tal via, justamente, que Lacan concebe o Real como forcluindo o sentido.

O sintoma, este efeito do simbólico no real (LACAN, 1974-5), não se pode afastá-lo com hermenêutica, impondo-lhe mais sentidos do que aqueles que ele em si já traz em excesso. Não, a operação parte do real, ao qual o simbólico poderá se rearranjar pela quebra ou torção de sentidos que as palavras-valise tão bem mostram. Mas o Real, como articulá-lo pela fala, sendo esta essencialmente simbólica? Heretizando-a, indo contra a doutrina do Simbólico como um sistema de codificação prévia, rompendo com suas leis, remontando aos

\footnotetext{
5 "Et c'est bien en quoi Joyce fait déchoir le Sinthome de son madaquisme [...] produit ce que j'appellerai le sint'home rule." (LACAN, 1975-6, p.14).
} 
elementos de Real da lalíngua, ${ }^{6}$ à fala primeira, despida das significações inertes e pretensamente inequívocas compartilhadas segundo uma lei ou código social preponderante.

Se pensarmos no herético à época do Fausto histórico-biográfico (que dá origem ao mito literário), esse se manifestava pela busca de incorporar à doutrina cristã vigente e mantenedora da verdade os valores e as ideias da Grécia clássica e pagã. Tal atitude é mais bem sucedida e tem melhor acolhida na Itália, onde, paradoxalmente, o catolicismo tem sua sede. Lá, a essa época, propõe-se uma forma de conciliação de valores que ganha o nome de Renascimento. Mas, anos antes, coube aos santos pensadores, Santo Agostinho e o nosso São Tomás de Aquino, sancionarem a conduta cristã frente a pensadores tais como Platão ou Aristóteles, decidindo e selecionando que aspectos e leituras de suas obras serviriam na aproximação do cristão em relação ao Deus inominável e todo poderoso e, por outro lado, quais o afastariam e o colocariam no caminho do mal.

Lacan resgata num católico, Joyce, a atitude de helenizar sua religião. É a tal atitude a que ele se refere ao abrir o Seminário 23, dizendo ser o que faz ao buscar (etimologicamente) o aspecto grego do sintoma, tal qual faz James Joyce em obras como Ulysses e em $\mathrm{O}$ retrato do artista quando/como jovem (A portrait of the artist as a young man).

Se os Faustos - histórico, lendários, míticos, poéticos — buscam injetar saberes heterodoxos nas doutrinas teológicas, essas injeções - é o termo que Lacan (1975-6 p.11) emprega — em Joyce aparecem de formas mais sutis e alusivas. Se em Ulysses ele traz a Grécia homérica para a Irlanda católica de seus tempos, no seu Stephen Dedalus, a helenização invade o nome da personagem-pseudônimo que alude tanto ao santo-mártir (Estevão), quanto à figura mítica (Dédalo) que criou suas asas para escapar do próprio labirinto em que se encerrara.

O Sinthome tem ligação direta com o que fazemos do legado paterno, a referência que nos introduz na realidade da cultura através da transmissão de suas insígnias; disso se trata no tão difundido conceito lacaniano de Nome-do-Pai. O Sinthome é uma quarta consistência que vem perverter o estabelecido, desacomodando e desatando suas estruturas prévias para propor uma nova articulação. É aí que entra o jogo homofônico entre perversion (perversão) e père-version (pai-versão). Essa rearticulação é uma nova tomada de posição diante do pai enquanto sintoma.

“Não é que sejam rompidos o Simbólico o Imaginário e o Real que define a perversão, é que eles já são distintos, e devemos supor um quarto, que é o Sinthome na

\footnotetext{
${ }^{6}$ Lalangue, no original da proposta lacaniana, que procura por esse termo designar a língua primeira, estabelecida mais entre os registros imaginário e real do que pelo jogo de substituições e codificações do simbólico. É, em suma, algo referente a lalação estabelecida na relação dual mãe-criança.
} 
ocasião, que se deve supor tetrádico, o que faz a ligação borromeana, que perversão [perversion/père-version] só quer dizer versão em relação ao pai, e que, em suma, o pai é um sintoma [symptôme] ou um Sinthome, como vocês quiserem. A ex-sistencia do sintoma [symptôme] é o que está implicado pela própria posição, aquela que supõe esta ligação — do Imaginário, do Simbólico e do Real — enigmática." (LACAN, 1975-6, p.8)

O Sinthome implica em tomar como diretriz a assertiva proferida no monólogo inaugural do Fausto de Goethe:

"O que de teus pais herdastes,

Conquista-o, para fazê-lo teu.” (682-3)

Essa citação nada teria de estranho à Psicanálise. Celebrizou-se em seu seio por ter sido o último, dentre tantos extratos do Fausto de Goethe na obra de Freud. Ela aparece na última página da última obra do psicanalista — Esboço da Psicanálise (Abriss der Psychoanalyse) (1938), uma obra que pretendia ser o apanhado geral, o compêndio, de toda a sua criação de um modo que facilitasse a apropriação pela cultura, o que lhe aufere um caráter iniludível de legado.

Cabe destacar que o termo que traduzimos por pais não preserva a ambiguidade da língua portuguesa. Eltern teria o sentido de genitores de ambos os sexos (pai e mãe), mas o termo utilizado por Goethe é Väter, plural de Vater (pai). O que nos importa aqui é uma característica que encontra eco naquilo que Lacan teoriza também no plural: os nomes do pai, e as nominações (plurais), versões dali possíveis.

Por certo, ao se tomar o jogo homonímico não se trata de induzir à perversão enquanto estrutura (clínica). Isso seria, além de feito impossível, a heresia despropositada, a vã blasfêmia. Trata-se antes de tomar dessa estrutura o seu modo de negação em relação ao Nome-do-Pai. Eis que nos vemos novamente diante de aberturas pelas sendas da homofonia e da equivocidade.

Indubitável a origem religiosa via in nomini patris..., mas, tomando o termo pelo francês de Lacan, temos uma proximidade sonora, se não perfeita homofonia, entre nom (nome) e non (não), que nada teria de casual. De fato, o ponto de encontro entre a religião e a Psicanálise dá-se no referente à interdição inerente e necessária ao estabelecimento de qualquer cultura ou inserção nela, interdição que se estabelece por uma renúncia negada: a renúncia à observação da falta (castração) no Outro. Mas se a religião aponta a necessidade dessa renúncia, é justamente, conforme teremos a possibilidade de observar, o que o Sinthome propõe superar ao seu modo nada denegatório. 
O termo estrutura, inclusive, foi usado por Lacan para diferenciar as consequências da forma de interdição e a também consequente negação operantes na aquisição da linguagem. Nesse momento, ele busca diferenciar as três negativas encontradas no texto freudiano e suas relações com três respectivas estruturas clínicas.

Ao Lacan joyceano, ou o último Lacan, já não cabe mais se ater tanto às estruturas e suas regularidades, as três (tridimensionais) estruturas procuravam separar e articular o que ele visa agora hereticamente a aproximar a partir de novas leituras. O Sinthome o faz repensar uma transformação do sintoma, fenômeno privilegiado como via de retorno do recalque, mecanismo próprio da neurose. Ele também re-elabora o estatuto da forclusão que ele aproxima da Verwerfung (rejeição) freudiana, desvencilhando-a de uma mera ineficácia psicótica e, voltando à perversão, poderíamos inferir que procura resgatar da denegação/desmentido (Verleugnung) o seu movimento de dupla inscrição: de negação e afirmação, conforme procuraremos demonstrar.

O Sinthome envolve uma atitude de escolha a partir do que é imposto, esse é seu caráter herético. Guarda-se aí um contrassenso, conotação figurativa da heresia: ${ }^{7}$ escolher o que é imposto pela forma outra de ser herdeiro (heréu). Nega a via canônica diante do pai, mas a assume, acrescentando a ela sua marca própria. Eis o movimento duplo e paradoxal próprio da denegação (Verleugnung). Procura a via alternativa que assim seria concebida diante de um Outro regulador que lhe faria frente, ainda que - eis a diferença básica em relação à perversão - este Outro não tenha, no Sinthome, conforme veremos, a mesma consistência. "Mas é fato que ele escolhe. Em que ele é, como eu, um herético. Pois haeresis, é aí que bem se especifica a herética. Deve-se escolher a via por onde tomar a verdade" (LACAN, 1975-6, p.15).

O posicionamento de Joyce frente a seu pai é ponto constituinte de grande ambiguidade ou ambivalência. Seus escritos, sobretudo o indiscutivelmente autobiográfico $A$ portrait of the artist as a young man, dão conta de uma atitude na qual, ao mesmo tempo que parece desmerecer e diminuir a importância desse pai, evoca tal importância por uma massiva presença. O livro começa com a voz paterna cantarolando uma canção ou improvisando uma estória bastante ridícula:

"Era uma vez e uma vez muito boa mesmo uma vaquinha-mu que vinha andando pela estrada e a vaquinha-mu que vinha andando pela estrada encontrou um garotinho engraçadinho chamado bebê tuco."

\footnotetext{
7 Do grego haíresis, 'escolha'; 'escola filosófica', 'seita religiosa', pelo lat. haeresis + -ia (HOUAISS \& VILLAR, 2001).
} 
O pai de Joyce, conforme se constata em biografias ou nos próprios trabalhos do escritor, é figura imponente e grandiosa, por um lado. Sabemos de seu orgulho quanto à linhagem familiar, seu engajamento na causa irlandesa, seu talento musical. Porém, paradoxalmente, seu pai (son père) soa (sonne) por vezes como um zé-ninguém (personne). Mas é sua a voz que introduz o exposto (abertura de Retrato do Artista...) e que o nomeia (baby tuckoo). Ele é evocado para dar sustentação ao discurso que funda a narrativa. Já ao final do livro, este mesmo pai aparecerá numa também paradoxal (prolífica e ridícula) "lista de ocupações” que visariam a dar-lhe, pela voz do filho, uma significação pela obra, pelo que faz ou produz. Tanto e, simultaneamente, quase nada:

“Um estudante de medicina, um remador, um tenor, um ator amador, um político gritão, um pequeno proprietário, um pequeno investidor, um beberrão, um bom camarada, um contador de histórias, secretário de alguém, algo em uma destilaria, um coletor de impostos, um falido e atualmente um enaltecedor de seu passado."

Atitude bastante ambivalente em que demonstra e afirma a importância por um lado (ainda que ridicularizando), e nega ao apresentá-lo tão depreciativamente como um bufo. ${ }^{8}$ Segundo Lacan, é paradoxalmente essa imago paterna a responsável pela obra de Joyce. Filho, na interpretação lacaniana, de um pobre-diabo, de um Fénian - para dessa vez ser Lacan o irônico, usando da proximidade entre Fénian (feniano, pertencente ao movimento político irlandês contrário à dominação inglesa) e fait-néant (faz-nada, preguiçoso): “foi sua arte que compensou seu porte fálico" (LACAN, 1975-6 p.15). E, mais adiante, ele complementa "esse coitado (ce hère) é concebido como um herói (héros)", produzindo o que, pela via aberta por Joyce e Lacan, poderíamos chamar de uma hére-éthique/héréthique. ${ }^{9}$

O pai é, portanto, um Outro cindido, barrado, ideia que, em si, já remonta a Freud e suas noções de aparato psíquico e de Ichspaltung (cisão do eu). Mas é Lacan quem o aponta no Outro, e não qualquer outro, mas sim naquele que é causador do sujeito como Eu Ideal, que Lagache descreve como a identificação heroica (apud LAPLANCHE \& PONTALIS, 2001, p.139). Não que essa noção não se aplique também à mãe, mas a ambivalência em relação ao pai tem suas peculiaridades que passam por questões tais como agressividade, temor, poder, honra, aspectos englobados em uma só noção: lei.

A falta (sin) de Joyce seria, nesse sentido, uma espécie de reedição do pecado de Cam, que apontou para seus irmãos a nudez e a embriaguez do pai. Falta que

8 "Ulysses, c'est le témoignage de ce par quoi Joyce reste enraciné dans son père en le reniant. C'est bien ça qui est son symptôme."

${ }^{9}$ Elemento que poderíamos associar a faunéthique que Lacan envolve no texto Joyce le Symptome (1975), texto-exposição que lhe dá o ensejo para o tema do Seminário 23. 
lhe rende a maldição rogada por pelo genitor que desperta: "Maldito seja Canaã!10 Que se torne o último dos escravos de seus irmãos.” (Gênesis, Cap. 9, Vers. 25) E mesmo que essa fúria não apareça na boca de John Stanislaus (pai de James Joyce), o medo da danação é uma constante no livro autobiográfico do escritor irlandês, com suas exaustivamente detalhadas descrições do inferno e castigos para aqueles que, como ele, fizeram por merecê-lo (JOYCE, 1996).

O Pai em nome de quem se deve erigir a lei é o evocado nas ações do bom filho. E Noé, que é pego por seu filho Cam de "calças curtas", ou antes, desprovido de calças e vestes, era, além do hedonista descobridor do vinho (e da embriaguez), o grande patriarca, construtor, provedor e redentor. Mas, nesse pai-homem, aparece a dupla natureza, que Cam percebe e ousa denunciar, fazendo-se, assim, talvez, o primeiro dos blasfemos.

Se a religião monoteísta toma a paternidade como a prerrogativa principal de seu Deus, questão que a Psicanálise desde Freud tão bem soube ler e articular, como poderia ser esse pai concebido sem mácula e falha? Esse pai fálico que, justamente no caso do Fausto pré-mefítico, busca-se alcançar a todo custo em sua perfeição, sabedoria, poder e gozo, vem parecer inatingível. É o modelo de uma identificação impossível. Mas, cabe aí remontarmos à forma como Freud apontaria a explicação para essa dupla natureza ou, antes, dupla inscrição.

Se, em textos tais como Totem e Tabu ou O futuro de uma Ilusão, Freud coloca, em sua concepção da natureza do sentimento religioso, a ligação de culpa-dívida (Schuld) com uma imago paterna onisciente e onipotente, o lugar para o pai-sintoma estará mais bem apresentado em seu breve Uma Neurose Demoníaca no Século XVII. (Eine Teufelsneurose im Siebzehnten Jahrhundert, 1922).

Deixando claro, já de início, as fortes influências do mestre de sua juventude, Jean Martin Charcot, que apontava nos casos medievais de bruxaria as manifestações da histeria em outros tempos, Freud seguirá semelhante caminho ao apontar uma leitura psicanalítica de um caso de possessão demoníaca. Eis, para irmos diretamente ao ponto, a concepção freudiana da dupla inscrição da imago paterna em sua forma religiosa:

"Para começar, [sabemos] que Deus é um substituto paterno ou, mais corretamente, que ele é um pai exaltado ou, ainda, que constitui a cópia de um pai tal como é visto e experimentado na infância — pelos indivíduos em sua própria infância, e pela humanidade em sua pré-história, como pai da horda primitiva e primeva. Posteriormente, na vida, o indivíduo vê seu pai como algo diferente e menor. Porém, a imagem ideativa que pertence à infância é preservada e se funde com os traços

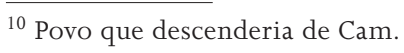


da memória herdados do pai primevo para formar a ideia que o indivíduo tem de Deus." (FREUD, 1922, p.331)

Como ele já adianta nesse trecho, em algum ponto adviria não só uma subvaloração, mas também a ambivalência:

“O problema não solucionado entre o anseio pelo pai, por um lado, e, por outro, o medo dele e o desafio pelo filho, proporcionou-nos uma explicação de importantes características da religião e de decisivas vicissitudes nela. [...] Com respeito ao Demônio maligno, sabemos que ele é considerado como a antítese de Deus, e, contudo, está muito próximo dele em sua natureza. [...] O demônio mau da fé cristã - o diabo da Idade Média — foi, de acordo com a mitologia cristã, ele próprio um anjo caído e de natureza semelhante a Deus. Não é preciso muita perspicácia para adivinhar que Deus e o Demônio eram originalmente idênticos — uma figura única posteriormente cindida em duas figuras com atributos opostos." (FREUD, 1922, p.331) (Grifo nosso)

Serve-nos aqui essa ideia do demônio-pai como o caído, ou talvez, anterior à ascese sagrada que somente advém, no que se refere ao pai-totêmico, após seu assassinato e a instituição da lei unificadora. Um pai ainda-não ou não-mais sagrado, no que nos faz lembrar sua aparência pré-humana, identificada ao animal totêmico (chifres, cornos e cauda) e que na imagem de Haizmann, do qual trata o texto de Freud, anterior à partilha dos sexos (demônio com pênis e mamas). Guarda-se aqui a chave para a Unheimlichkeit, ou estranheza familiar, que denota esta imagem do demoníaco, sobretudo na figuração híbrida (parte animal/ parte humano) que lhe reserva o cristianismo medieval, com a definição que Freud (1919) empresta de Scheling: “'Unheimlich’ é o nome de tudo que deveria ter permanecido... secreto e oculto, mas veio à luz”.

Teremos oportunidade de retomar a problemática do diabo como tendo relação com um Nome-do-Pai destituído de um lugar ideal, mas cabe introduzirmos a ideia que Freud esboça em Totem e Tabu do pai da horda como um pai-diabo. Como coloca Luisa de Urtubey em seu Freud et le Diable (Freud e o Diabo): “Ele não recalca suas pulsões (O diabo = a personificação da vida pulsional), ele tem traços animais (como o diabo com sua cauda e seus chifres) e, além do mais, seu narcisismo não seria, afinal, uma característica demoníaca (Lúcifer, a mais bela criatura)?" (1983, p.99).

No que trazemos deste resto do pai oculto (heimlich) nas trevas em contraposição ao pai Ideal, manifesta-se a noção de Spaltung freudiana concernente não ao $\mathrm{Eu}$, mas sim àquele que lhe serve de ideal enquanto alicerce para a constituição subjetiva pelo campo do discurso, da figura que estaria na base da formação do supereu. A boa heresia atribuída por Lacan a Joyce no Seminário 23, acerca do Sinthome, 
teria a ver com a aceitação da imago paterna, porém não tão somente enquanto o ideal, lugar-comum e forma pasteurizada de conceber o evento. Joyce recorre ao pai fazendo-o figurar como sujeito titânico, exuberante, galante, encantador, mas também no que esse tem de ímpio, de pobre-diabo, para poder fazer com essa herança um artifício que lhe resulte proveitoso. Joyce se depara de maneira iniludível com a castração deste Outro (A/) desde sua inscrição, mas, ao invés de negá-la pelo delírio, pelo fetiche ou pelo recalque, faz uso disso em sua arte.

Trata-se de algo que deve ser conquistado a partir do que é imposto enquanto carência. Algo que apontaria para o essencial do mito de Fausto no que preserva de estrutural em suas versões: o comércio com o demônio. Não do todo-poderoso Lúcifer, belo e magnífico portador da luz, mas do demônio bufo, rasteiro, vulgar e escarninho, tal qual se caracteriza na figura de Mefistófeles, aquele que não ama a luz. Cabe aqui lembrarmos a passagem em que Lacan aponta ao esplendor do Ser, aludindo à claritas de São Tomás em relação às trevas e à superação desta dicotomia luzes-trevas que aparece ao final do Seminário, quando trata do Real: "O obscuro não passa de uma metáfora, pois se soubéssemos uma ponta do real, saberíamos que a luz não é mais obscura que as trevas e vice-versa” (1975-6, p.124).

Segundo Thomas Mann (apud CAMPOS, 1981, p.81), o nome desse demônio teria algo que ver com "mefítico" (sulfuroso, pestilencial) "pois se trata de um tipo ignóbil, ignóbil em alto estilo, porém com um sentido de humor dominando a sua sujidade”. Eis aí também o que podemos apontar como característico do que Lacan teoriza sobre a negação na psicose: suas buscas de união entre o escatológico e o sublime, a forclusão e suas consequentes supleções ou suplências. Lacan propõe uma articulação com a negação na psicose, e essa teria uma característica distinta das outras duas estruturas (Neurose e Perversão) no que tange aos três registros da experiência psíquica: o real, o simbólico e o imaginário.

Na neurose e na perversão, o significante Nome-do-Pai, o primeiro e inaugural, instala-se fundando o registro do simbólico e é nele, no jogo metafórico das substituições alusivas, que o negado retorna. É próprio do simbólico o artifício da troca: de uma coisa pela palavra, de um símbolo por uma ideia, mas uma troca sempre inexata e, ainda que bastante arbitrária em sua natureza, seguindo um código passível de ser compartilhado. Na neurose, modelo primeiro da Psicanálise, o que é negado é rechaçado (verdrängt) enquanto tal para retornar transformado no sintoma. Na perversão há uma dupla inscrição de concomitante afirmação e negação, o que é negado retorna, por exemplo, no fetiche.

$\mathrm{Na}$ psicose haveria, porém, algo de distinto. O retorno do negado dar-se-ia não no simbólico, mas sim no real. E isso não por outro motivo que a falha na própria inscrição desse significante, o Nome-do-Pai, a partir da metáfora paterna e consequente ascese ao simbólico. Essa “lei” paterna, no caso da psicose, não se incorpora ao simbólico. "Sendo então foracluído o significante Nome-do-Pai, ele 
retorna no real sob a forma de um delírio contra Deus, encarnação de todas as imagens malditas da paternidade" (ROUDINESCO \& PLON, 1998, p.542). O delírio, que seria entendido como busca de cura na psicose, etimologicamente remete a uma tomada alternativa de caminho ou rumo preconcebido. Mas o delírio de Joyce não é o alucinatório, e sim o da sua arte, de seu artifício.

Semelhante caminho seguem autores que expressam em seus Faustos a ligação com esse pai às avessas, ainda que, mister faz-se adiantar. Fausto abandona o Deus Ideal, metáfora substitutiva do pai, para entrar em contato com a figura chã de Mefistófeles e, a partir de um pacto, fazer uso de seus poderes incorporandoos à sua maneira, de acordo com seu desejo. O pai deixa de ser substituto e abre o caminho para as suplências, incorporando a esse poder a marca própria do "filho", assinando com o próprio sangue o próprio nome apropriado do pai. Retomando a negação-afirmação, Fausto busca aquilo que Lacan indica em Joyce: “Do Nome-do-Pai se pode também prescindir... à condição de servir-se dele" (1975-6, p.136).

Recebido em 19/6/2008. Aprovado em 29/10/2008.

\section{REFERÊNCIĀS}

BÍBLIA SAGRADA. (2002) Tradução da CNBB. São Paulo: Edições Loyola. CAMPOS, H. (1981). Deus e o Diabo no Fausto de Goethe. Leitura do Poema, acompanhada da transcrição em português das duas cenas finais da Segunda Parte. São Paulo: Perspectiva.

FREUD, S. (1999) Gesammelte Werke. Chronologisch geordnet, Frankfurt am Main: Fischer Verlag.

(1905) Der Witz und seine Beziehung zum Unbewußten, v.VI, p.1-285.

(1919) Das Unheimliche, v.XII, p.227-268.

(1922) Eine Teufelsneurose im siebzehnten Jahrhundert, v.XIII, p.315-253.

(1938) Abriss der Psychoanalyse v.XVII, p.63-138.

GOETHE, J.W. v. (1997) Faust I und II. Colônia: Könemann, 1997.

JOYCE, J. (1922/1998) Ulisses — Tradução de Antonio Houaiss. Rio de Janeiro: Civilização Brasileira.

(1996) A Portrait of the artist as a young man. Londres: Penguin.

LACAN, J. (1949/1999) Le Stade du Miroir Comme Formateur de la Fonction du Je, in Écrits I. Paris: Seuil. (1974/1975) Séminaire 22 — RSI, (Inédito). (1975/1976 /2003) Le Séminaire — Livre XXIII — Le Sinthome. Paris: Seuil. (1975a/2001) Joyce le Symptôme, in Autres Écrits. Paris: Seuil. 
LAPLANCHE, J. \& PONTALIS J.B. (1982/2001) Vocabulário da Psicanálise. São Paulo: Martins Fontes.

MARLOWE, C. (2003) Doutor Fausto. The tragical history of the life and death of Doctor Faustus (Edição Bilíngue). Sintra: Publicações Europa América. ROUDINESCO, E. \& PLON, M. (1997) Dicionário de Psicanálise. Rio de Janeiro: Jorge Zahar Editor.

URTUBEY, L. (1983) Freud et le Diable. Paris: Presses Universitaires de France.

Pedro Heliodoro de Moraes Branco Tavares

pedrohmbt@hotmail.com 